\title{
The Impact Psychological Empowerment in Achieving Job Satisfaction at the Police College, Qatar
}

\author{
Khaled M. A. AL-Hajri ${ }^{1}$ \& Abdallah Mishael Obeidat ${ }^{2}$ \\ ${ }^{1}$ Police College, Qatar \\ 2 Jadara University, Jordan \\ Correspondence: Abdallah Mishael obeidat, Jadara University, Jordan. E-mail: aabdullahh2000@hotmail.com
}

Received: May 17, 2019

Accepted: June 30, 2019

Online Published: August 5, 2019

doi:10.5539/ijbm.v14n9p1

URL: https://doi.org/10.5539/ijbm.v14n9p1

\begin{abstract}
This study aims at discussing the impact of the psychological empowerment (in terms of sense of influence, freedom of choice, sense of capability and sense of importance) in achieving job satisfaction at the Police College of Qatar. To achieve this goal, the authors of the research adopted an analytical and descriptive approach based on a survey that they have designed and distributed to focus group of 186 employees, from which 173 respondents returned replies which were analyzed. The research concluded that there is an impact of the psychological empowerment with its various dimensions in achieving job satisfaction at the Police College of Qatar. Therefore the study recommends the adoption of methods and procedures that would enhance the employees' involvement in the administrative and operational affairs relating to their duties and their activities, and working on generating and enhancing the feelings and ideas which would make them feel the importance of the job they are performing.
\end{abstract}

Keywords: psychological empowerment, sense of influence, freedom of choice, sense of importance, job satisfaction, Police College, Qatar

\section{Introduction}

Job satisfaction is a topic which deserves more attention from the management of any organization, given the important role it plays in determining the employees' behavior (Masa"deh et al., 2019). It has gained the attention of many scholars specializing in the study of behavior. Moreover, the employees' satisfaction is one of the subjects surrounded by some ambiguity in the management sciences because it is an emotional state of the employee which is hard to understand (Belkili \& Ashit, 2012). Concerning the employees who are tasked with a job, they are willing to do that job only when there is a motive to do so and this is only possible through job satisfaction, that means through the benefits and advantages they are receiving from the work, and which stimulate them to do their best efforts to achieve the work assigned to them (Sultan, 2014).

Psychological empowerment is an important concept and it involves the creation of mutual trust between the employee and the organization management to achieve an effective personal capability through delegation of powers to the employees, granting them independence and freedom of action and stimulating them by material and moral incentives. This leads to job satisfaction which indicates the positive or negative feeling of the employees which reflect the level of their satisfaction of the work they are doing within the organization. Both terms are new administrative terms relating to the employees' attitude while making their best efforts to achieve excellence within their organization (Zeglat et al, 2014). Therefore, psychological empowerment is an important requirement for the application of the modern management concepts, and since it involves the achievement of an added value within long-term plans and objectives, it is necessary to adopt this concept in order to achieve satisfaction of the employees and create positive attitudes towards work (Darraji, 2018).

Given the importance of psychological empowerment and job satisfaction, several studies discussed these two concepts emphasizing on their importance in the work environment. Among these studies, we can mention the study conducted by Hussein (2016), Jaradat, Maani and Hashem (2013), Zeqlat et al (2014) and many others which referred to the importance of the psychological empowerment in achieving the job satisfaction of the employees and increasing their loyalty to their organizations.

Organizations in general and the Police College of Qatar in particular are facing many difficulties in achieving 
the job satisfaction among its employees. Reasons for that are: first, the pressure exerted on the Police College due to its young age and the diversity of its activities besides being the sole and only college dealing with police education in the country. Second, the pressure on the college employees resulting from the nature of the college's activities and operations and which require the adoption of some measures to ease this pressure, including psychological empowerment. Based on the above, this research is aiming at responding to the following question: Does psychological empowerment have any impact on job satisfaction?

\section{The Psychological Empowerment}

Empowerment has drawn the attention of many scholars, researchers and professionals because of its important role in the development of organizations (Gautam \& Ghimire. 2017, p. 466). Empowerment is considered as an effective means of human resources development resulting in the consolidation of the organization's competitiveness. Nowadays, the introduction of high tech and advanced methods is no more a subject of competition between organizations neither a source of any advantages in terms of competitively. Creativity, positivity, quality, personal capabilities and intellectual, mental, psychological and physical skills have become the fundamental elements of competitivity between organizations whatever their size or activity (Khalidi, 2018; Abualoush et al., 2018).

Many studies have shown the effectiveness of empowerment in making the employees feel confident and capable, and this, encourages them to be more creative and positive and stimulates them to do their job and fulfill their duties in a better way and all this will reflect in achieving job satisfaction (Greasley et al 2008). Empowerment is one of the best tools aiming at involving employees in the decision making process and in taking responsibilities and this will result in more creativity, self-confidence and productivity, thus in more job satisfaction (Paktinat \& Fathizadeh, 2008)

Psychological empowerment is one of the most important psychological needs of individuals since it increases their feeling of capability, control and independence in fulfilling their duties and making the right decisions, because it is based on the principle of participation of all employees in the different management levels and focuses on the psychological dimension of empowerment and its effect on the psychology of the employees and their performance. It also involves the personal factors and variables which are affected by the empowerment and thus affect the organization (Spreitzer, 2008). In addition, it addresses the psychological factors and the impact of the wrong or correct application of some administrative practices on the employees (Abu Tbikh, 2018, 185).

Speitzer described the empowerment as being a motivational tool and a push-forward method which manifests through four basic perceptions, namely influence, independence, merit and significance. The absence of one of these perceptions does not abrogate the empowerment but will distort its meaning which is based on two hypotheses. The first hypothesis is that empowerment is a system of perceptions resulting from the organizational environment and therefore it is not a permanent personal character which could be generalized in different situations. The second one is not linked to the individuals presence, which means that employees are either more empowered or less empowered, in contrast with empowered and not empowered at all. According to Carless, empowerment is a set of psychological feelings and motives which are inherent to the working individual and cannot be granted to him. The role of the management is to take care of it through creating the appropriate environment and support to reinforce it (Abazaid, 2010, p. 500). Dewttink and Ameijde (2011, p. 285) described the empowerment as being the activity leading to the improvement of the employees' attitudes and orientations and boosting their job satisfaction and self-commitment, besides the refinement of the basic behavioral adherence based on abiding and executing the orders and the emotional behavioral adherence based on the emotional attachment to their colleagues.

Menon describes empowerment as a contractual relationship between the management and the employees in an organization and its application requires certain conditions. Empowerment is measured according to many aspects such as influence, importance, capability (merit) and independence. It is a permanent feeling which is not limited in time and its proportion varies for all employees and it is not linked to the existence or non-existence of empowerment but to its amount or degree, a little or plentiful of it (Berni, 2014, p. 11).

The importance of empowerment is reflected through its role in enhancing the efficiency and motivation of the employees because their perception of empowerment helps them feel their personal power and efficiency, which are reinforced by the support provided by the management (Karkat, 2017, p. 22), thus creating a sense of responsibility towards the organization to which they belong and increases the employees' motivation and efficiency in doing their job. This will reflect positively on the progress of work and on the organization's ability in achieving its goals and objectives (Ugwu, Ike, Maria, Sanchez, 2014, p. 381). The positive effects of 
psychological empowerment are also reflected through the ability and the easiness in performing the tasks and the consolidation of cooperation ties and team work, allowing the employees to contribute in the management and operational strategies of the organization, which will result in enhancing its ability to achieve its objectives and increase its productivity (Sacidi \& Asgari, 2016). Psychological empowerment is also a motivation factor which encompasses four dimensions, namely, the sense of influence, the freedom of choice, the sense of capability and the sense of importance. Together, these four dimensions reflect the positive orientation of the employees towards their work and their organization as they enhance their ability to possess the very faculties and skills which enable them to make decisions which are compatible with the organizations objectives.

The following is an explanation of these dimensions (Al Hussaini, 2015, p. 174):

\subsection{The Sense of Influence}

The sense of influence suggests giving the employees the feeling and the perception of being influential in the work process, in the other employees' performance and in the achievement of the organization's objectives (Al Taai \& Kadada, 2008, 243). The perception by the individual that he is contributing in the strategic, managerial and operational results of the organization and in the outcome of the tasks assigned to him, makes him feel influential. Influence is the reflection of the individual's beliefs and perceptions of his ability to influence the course of his work and the response of the other employees to his opinions and thoughts. This feeling makes the employee aware of his importance and his contribution in the decision-making process within the organization and in the policies adopted by it, especially in terms of works and tasks assigned to him. This feeling grows as much as the influence of the individual increases in matters relating to his work, particularly those of great importance. This feeling is enhanced the more the influence in matters related the organization's goals and objectives grows. And this will positively reflect on his motivation towards his work and raises his morale and therefore increases productivity. The opposite is true. The influence over insignificant matters would create a feeling of being unimportant and deprived from influence resulting in limited motivation and frustration which lead to apathy and neglect, thus to a drop in productivity.

\subsection{Freedom of Choice}

Freedom of choice reflects the degree of freedom granted to an employee to do the job assigned to him. It involves the ability to choose and take decisions according to work methods and procedures he deems appropriate to the limit of his power and responsibility, and this is achieved through participation in doing the job and performing the tasks in a positive and effective way (Ugwu et al, 2014, 283).

The importance of freedom of choice and independence granted to individuals is shown through the increase of their feeling of being efficient and able to perform the work assigned to them with the required flexibility resulting in an increased job satisfaction and reinforced motivation and enthusiasm in facing the work stress, problems and obstacles that hinder the workflow by taking initiatives, finding solutions and taking the appropriate decisions in order to achieve the desired results. Moreover, granting enough freedom of choice and independence to the employees will increase their self-esteem and improve their capabilities and skills resulting in an increased efficiency and productivity and thus contributing effectively in achieving the organization's objectives of development and prosperity (Saeidi \& Asgari, 2016).

\subsection{The Sense of Capability}

Capability means the possession by the employee of personal competence and resolution to confront and the readiness to develop his skills (Al Kalidi, 2018, p. 9). The sense of capability reflects the individual's faith in his talents, potential and skills, and in his ability to complete the work assigned to him. The importance of the sense of capability stems from its direct impact on the individual's work results and outcome, because when he feels confident in his ability to perform his duties as required, he will reach the desired results (Joo \& Lim, 2013). The sense of capability also highlights the degree of self-confidence of the employee and his ability to face challenges and overcome obstacles, and this will reflect positively on the work progress within the organization. Moreover, capability reveals the need for learning and training to acquire new knowledge and skills leading to improve the level of performance of the organization. The efficient supervision and motivation for creativity and innovation, besides the training of employees and the development of their skills are among the best means to promote the sense of capability of the staff (Shahine, 2015; Obeidat\&Otibi, 2015).

\subsection{The Sense of Importance}

This means giving the employees the feeling that the work they are doing is important and valuable (jallab, 2011, 447). The sense of importance reflects the employee's perception of the real value of his work and his effort. This feeling is associated with the employee's thoughts and beliefs towards his role as a significant and useful 
role.

This contributes in creating a state of balance and harmony between his beliefs and his behavior. The sense of importance is generated from the assessment by the employee of the objectives of his role according to his thoughts and beliefs and in the light of some standards defined by him, and is subject to three basic factors, namely the multiplicity and diversity of skills, the importance of the work and the performance of the work and tasks (Al Hussaini, 2015, p. 175).

The perception by the employees of the importance of their role in achieving the overall objectives of the organization, the feeling that the work they are doing is useful for the organization and for the society in general, and the motivation for making use of their skills and capabilities will raise their awareness of the importance of their role and this will result in an increased productivity and more interest in the events and changes going on in the organization (Al Jady, 2017, p. 21).

\subsection{Job Satisfaction}

The issue of Job satisfaction has received great attention from many researchers and scholars specializing in management, psychology and other disciplines. This resulted in a great number of studies and researches which addressed this topic from several perspectives (Adel, 2010, 85). The industrial sector is one of the first sectors which showed great interest in the job satisfaction considering it among the fundamental topics related to work (Beriah\& Moussawi, 2016, 3). This interest generated from the thoughts presented by Frederic Taylor in the twenties of the last century stating that the increase of productivity could be achieved by adopting a scientific approach in reorganizing the work and introducing a salary policy linked to the productivity and reinforcing the morale of the employees. It is worth noting that these thoughts have emphasized on the content of work, considering it as the main factor in determining the level of job satisfaction. These thoughts have subsequently developed and were centered on the employee as the one who will determine the job satisfaction (Gunim, 2018, 197).

Job satisfaction is considered as one of the indicators that show the quality of the professional life of the organization's employees regardless of productivity. It involves that all daily events that happen to them will have repercussions on their overall personal life and their general attitude towards life (Smith \& Tugba, 2016). Job satisfaction is defined as a feeling of happiness shown by an employee towards his work (Al Sairafi, 2008, 131). Wang defines the job satisfaction as the expression by an employee of emotional, corporal and mental feelings towards his work's environment (Wang, 2012, p. 176). Piriyathanalai and Muenjohn Define it as the positive evaluation by the employee of his job and his work and which is affected by the work regulations and policies and by his position within the organization (Piriyathanalai \& Muenjohn, 2012, 90). While Karmani defines the job satisfaction as being the positive emotive attitudes and states resulting from the overall evaluation made by the employee of their job (Kermani, 2013, p. 134). Hajjaj (2015) considered that the job satisfaction represents the reactions resulting from the comparison made by the employee between his expectations and what he gets in the reality from his job. This comparison is the basis of differentiation between many alternatives when choosing a work or an activity which might provide him what he was expecting so that the expected benefits are equal to those he is getting in reality, be it material or moral benefits.

The importance of job satisfaction emanates from its correlation with the human resources which are among the most important assets of any organization and represents its real wealth and basic pillar for the achievement of its objectives, enhancing its ability for development, prosperity and stabilization. To optimally benefit from these resources, the organization shall take care of its human resources and endeavor to satisfy their needs and aspirations to help them achieve the reconciliation between their expectations and the benefits they obtain from their work. This would create positive feelings towards the work conditions and have positive repercussions on the work (Al Maeeni, 2018, p. 40; Obeidat et al., 2018). Such feelings would increase the employees' motivation and improve their morale resulting in a decrease of the rate of absenteeism and resignations and in a drop of the number of claims, grievances, and deviations and the limitation of disputes between themselves or between them and the management (Jouda, 2010, p. 45). These feelings also strengthen the employees' loyalty and commitment to the organization, thus contributing in its distinction and in increasing its efficiency and effectiveness (Nalhotra \& Mukherjee, 2008, p. 174). Moreover, the feeling of satisfaction contributes in creating a state of psychological and social harmony which leads to professional success and therefore to the improvement of productivity (Bin Muwafaq \& Bin Safi, 2017, p. 26).

\subsection{Psychological Empowerment and Job Satisfaction}

According to Light's study conclusions, mentioned by Tamidi (2010), it comes out that the Psychological empowerment is extremely important for the employees as it creates in them positive feelings and high job 
satisfaction (Tamidi, 2010, p. 238). A study conducted by Indradevi pointed out that there is a correlation between the psychological empowerment and the job satisfaction. In fact, the increase in psychological empowerment of the employees through their involvement in the decision-making process and in the management of the organization would increase the rate of job satisfaction. The opposite is true. The increase of the psychological empowerment of the employees would create a feeling of non-satisfaction. The amount of psychological empowerment and job satisfaction is reflected in the employees' productivity (Indradevi, 2011). Another study by Hassan \& al stated that the psychological empowerment affects the degree of job satisfaction of the employees in a positive and direct way (Hassan, 2014). In separate studies, Priyadharshany and Sujatha (2015), Cingoz and Kaplan (2015) and Imam \& Hassan confirmed that the increase of job satisfaction is a result of enjoying higher levels of psychological empowerment. A study by Abdissa and Fitwi (2016) concluded that psychological empowerment has a real impact on the degree of job satisfaction. The same conclusion was made by a study conducted by Khanna and Gupta in 2016.

Similarly, a study by Chegini and Abadi concluded that there is a positive correlation between the psychological empowerment (the sense of capability (merit), the freedom of choice (independence) and the job satisfaction of the employees. In fact the level of job satisfaction is function of the increase of the psychological empowerment (Chegini \& Abadi, 2013). Chong \& Ian, stated in their research that the sense of importance (meaning) is one of the most important factors affecting many aspects relating to employees, including job satisfaction, as reaching the highest levels of job satisfaction could be achieved through improving the positive attitude of the employees towards the importance and the value of their work (Chong \& Lan, 2014).

Saeidi and Asgari explained that freedom of choice (independence), which is one of the psychological empowerment' aspects, is likely to contribute effectively in enhancing the individual capabilities and skills of the employees and increasing their efficiency and productivity, thus their job satisfaction (Saeidi \& Asgari, 2016). On the other hand, several studies, such as the one conducted by Lari\& al in 2012 and the other one by Bested in 2013 and by Sabir and Kalyar in 2013 concluded that providing the employees with psychological empowerment would increase their creativity and their innovation abilities and motivate them to adopt creative behaviors and practices when doing their work. The tendency of the employees to creativity and innovation is a result of their satisfaction towards the work they are doing.

In their studies, Demgrcq (2010), Meyerson and Dewettinck (2012), Nzuv and Bakari (2012) and Mir and Rainayee (2015) stated that there is a direct correlation and a positive effect of the psychological empowerment and the job satisfaction, as empowering the employees with appropriate and sufficient psychological support and encouragement and moral empowerment, would increase their efficiency, productivity and their ability to perform the tasks and duties assigned to them. Reaching this level of performance in a context of psychological empowerment will result in a feeling of job satisfaction towards the organization and their work as the psychological empowerment will make them feel flexible, independent, able to make decisions and achieve professional stability and hence be motivated to take the responsibility (Screenivas, 2014), which is considered as one of the job satisfaction indicators.

It is clear from the above that all studies are positive concerning the correlation between the psychological empowerment and the job satisfaction. However, this does not negate the existence of some other studies which concluded the existence of a negative correlation between them while some other researches confirm the non-existence of any relation between the psychological empowerment and the job satisfaction. Among these studies, the one conducted by Dickson \& Lorenz in 2009, which concluded that there is a negative correlation between the freedom of choice (independence) and the job satisfaction and that there is no correlation between the sense of importance (merit) and the job satisfaction.

Wand and Lee (2009) concluded the variation of the impact of the freedom of choice on the job satisfaction depending on the level of the sense of influence and the sense of importance. The increase in one of these two aspects and the decrease of the other will reflect positively on the impact of the freedom of choice on the job satisfaction, while it negatively affects the job satisfaction in case of an increase or a decrease in the sense of influence and the sense of importance. The study also concluded the absence of any role of the sense of influence in the job satisfaction in case of an increase or a decrease in the sense of influence and the sense of importance. Its positive role is confirmed in case of the increase of one the two aspects and the decrease of the other. In his study published in 2011, Wasihun claimed that there is no correlation between the psychological empowerment and the job satisfaction. 


\section{Theoretical Model and Hypotheses}

This section provides the methodology applied in the current study. It consists of the research model, operational definitions of independent and dependent variables, research hypotheses and date collection tool and research population and sample.

\subsection{Research Model}

The principal elements of the current study are based on the previous literature, theoretically and experimentally. In fact, this study used the common dimensions in the literature of psychological empowerment. Fig. 1 is a research model showing the independent variables of the psychological empowerment, the dependent variable (the job satisfaction) and the proposed correlation between them. The current study presents four independent dimensions of the psychological empowerment and one dependent variable (the job satisfaction). In order to achieve the study's objectives and reach the desired conclusion, the author of this study adopted the following model to discuss the correlation variables.

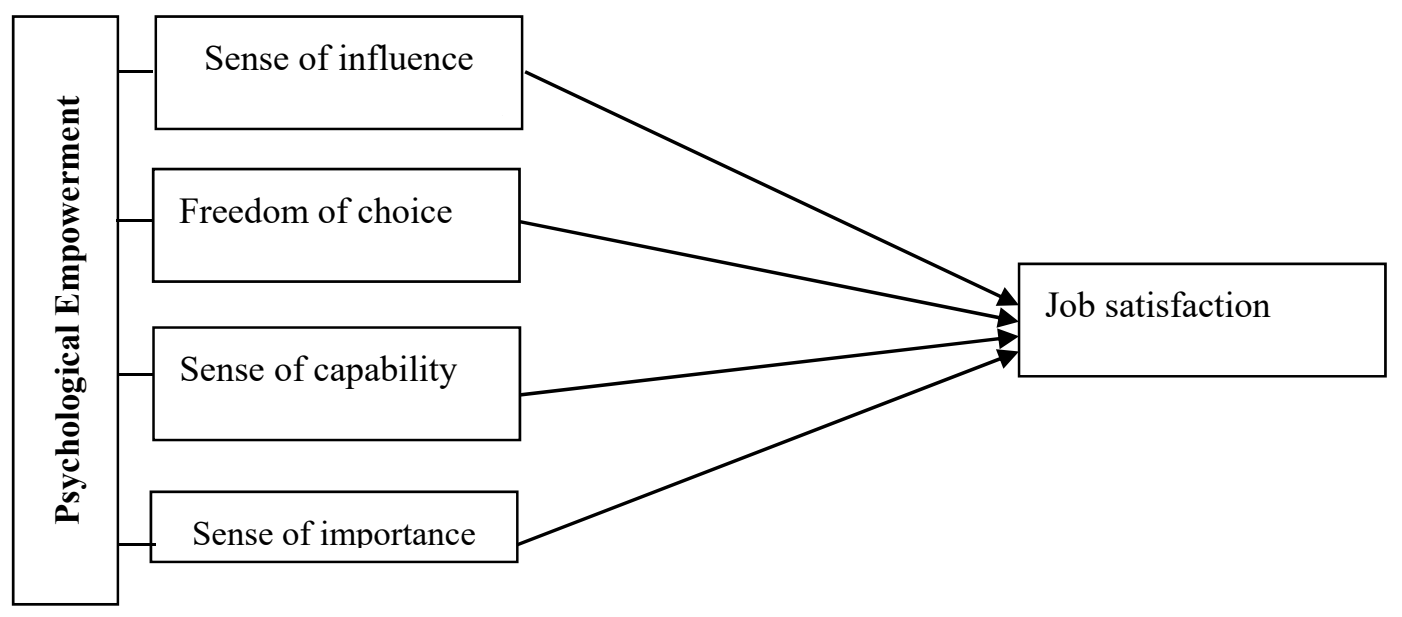

\subsection{Research Hypotheses}

The psychological empowerment plays an important role in making the employees of an organization do their professional duties in a more positive manner. In fact, some studies claimed that a high level of psychological empowerment may increase the job satisfaction, lower the job-related stress and deeply affect the employees' efficiency (George, 2013), (Hamady, 2017), (Joo \& al 2013). From this point, we can formulate the research hypothesis:

Statistically, there is an impact of the psychological empowerment with its different dimensions (sense of influence, freedom of choice, sense of capability, sense of importance) in achieving job satisfaction.

\subsection{Research Method}

The co-authors have designed a survey (questionnaire) that consists of three parts. The first part includes the demographic data of the respondents, namely their age, education, job experience and professional grade. The second part is about the psychological empowerment with its four dimensions: the sense of influence, the freedom of choice, the sense of capability and the sense of importance and include 20 paragraphs (George, 2013) (Mardani \& Mardani, 2014). The third part is dedicated to job satisfaction and includes 12 paragraphs (Joe et al, 2013), (Darraji, 2018).

The survey was dedicated to the Police College staff, i.e. 450 employees. The Sekaran tables were used to determine the size of accepted samples, which consisted of 207 employees (Sekaran \& Bougie, 2010). The authors distributed the questionnaire to the sample members from which 186 were retrieved, 13 were rejected for not being complete and 173 were good for analysis, that means a retrieval proportion of $83.6 \%$ which is deemed an acceptable rate.

The questionnaire adopted the measuring method based on Likert quinary scale to determine the weight of each paragraph relating to the measurement of each variable of the study and determining its general level starting with 1 . Strongly don't agree, 5. Strongly agree. 


\section{Data Analysis and Results}

To answer the questions of the survey and validate its hypotheses, the method of Descriptive and Analytical Statistic Measures was adopted by using the Statistical Package for Social Sciences (SPSS) to conduct the different statistical analyses and tests. To achieve the purpose of the research, the Descriptive Statistic Measures was used to determine the percentages, repetitions, arithmetic averages and the normative deviations to describe the sample's properties and give a comprehensive description of the employees' degree of approval of the different paragraphs of the survey. The internal consistency coefficient (Cronbach Alfa) was used to measure the consistency of the study tool which consists of the questionnaire. The Multiple Linear Regression Analysis and the Variation Inflation Factor (VIF) was used to validate the study's sample and to test the effect of the independent variable on the dependent variable. The proportional importance was determined according to Likert Quinary scale applied to the number of levels: low, medium, high.

\subsection{Validity and Reliability}

The apparent honesty of the questionnaire was tested by a board of arbitrators chosen among experimented academicians who were asked to give their opinion about the validity of the questionnaire for the collection of data, its clarity and consistency and make any comment they may deem appropriate for correction or elimination. The arbitrators' remarks and proposals based on the review and audit of the questionnaire were taken into account and some modifications were carried out in order to prove the apparent honesty of the tool. Therefore the questionnaire was deemed valid to measure what it was designed for.

The stability of the questionnaire in measuring the variables was tested by using the Cronbach Alpha Coefficient. According to this method, the measuring result is statistically acceptable if the value of Cronbach Alpha is superior to 0.60 (Sekaran, 2006, p. 311) and the more the value is close to $100 \%$, the more it proves that the study tool is stable.

Concerning the data of the following table, the Cronbach Alpha Coefficient was used to measure the variables of the study as a whole to know the degree of consistency of answers.

Table 1. The internal consistency coefficient of the study paragraphs

\begin{tabular}{llll}
\hline The Number & The dimension & Number of paragraphs & Alpha value \\
\hline 1 & Sense of influence & 5 & 0.750 \\
2 & Freedom of choice & 5 & 0.760 \\
3 & Sense of capability & 5 & 0.741 \\
4 & Sense of importance & 5 & 0.783 \\
Psychological empowerment & 20 & 0.878 \\
Job satisfaction & 12 & 0.781 \\
Total & 32 & 0.907 \\
\hline
\end{tabular}

\subsection{Respondents Demographic Profile}

This chapter contains the demographic profile of the survey respondents i.e. age, education, professional experience and the career level. For the purpose of defining the sample's characteristics, repetitions, demographic variables rates and personal details of the respondents were determined as the following: 
Table 2. Demographic profile of survey respondents

\begin{tabular}{llll}
\hline Variable & Category & repetition & Percentage $\%$ \\
\hline \multirow{4}{*}{ Age } & Below $30 \mathrm{y}$ & 74 & $42.8 \%$ \\
& $30-40 \mathrm{y}$ & 72 & $41.6 \%$ \\
& $41-50 \mathrm{y}$ & 18 & $10.4 \%$ \\
Above 51 & 9 & $5.2 \%$ \\
Total & $\mathbf{1 7 3}$ & $\mathbf{1 0 0 \%}$ \\
diploma or less & 64 & $37.0 \%$ \\
Education & Bachelor & 79 & $45.7 \%$ \\
& Master & 16 & $9.2 \%$ \\
& PhD & 14 & $8.1 \%$ \\
& Total & $\mathbf{1 7 3}$ & $\mathbf{1 0 0 \%}$ \\
Less than $5 \mathrm{y}$ & 65 & $37.7 \%$ \\
Experience & $5-10 \mathrm{y}$ & 48 & $27.7 \%$ \\
& $10-15 \mathrm{y}$ & 30 & $17.3 \%$ \\
& 15 and above & 30 & $17.3 \%$ \\
& Total & $\mathbf{1 7 3}$ & $\mathbf{1 0 0 \%}$ \\
& Director/DG & 0 & $0.0 \%$ \\
Depart. head & 4 & $2.3 \%$ \\
& Officer & 16 & $9.2 \%$ \\
& NCO & 18 & $10.4 \%$ \\
& Constable & 76 & $43.9 \%$ \\
& Employee & 59 & $34.2 \%$ \\
Total & $\mathbf{1 7 3}$ & $\mathbf{1 0 0 \%}$ \\
\hline
\end{tabular}

\subsection{Descriptive Analysis}

The answers of survey respondents were described using the arithmetic averages, the standard deviations and the relative importance for each section of the survey. The level is considered as low if the arithmetic average is between 1.00 and 2.33, mean if the arithmetic average is between 2.34 and 3.67 and high if the arithmetic average is between 3.68 and 5.00 .

Table 3. Arithmetic averages, standard deviations, ranks and levels of the education variable

\begin{tabular}{|c|c|c|c|c|c|}
\hline Type of variable & Variables & Mean & Standard deviation & Order & Level \\
\hline \multirow{5}{*}{ Independent variables } & Psychol. empowerment & 3.777 & 0.440 & & high \\
\hline & Sense of influence & 3.584 & 0.495 & & mean \\
\hline & Freedom of choice & 3.880 & 0.601 & & high \\
\hline & Sense of capability & 3.855 & 0.633 & & high \\
\hline & Sense of importance & 3.787 & 0.534 & & high \\
\hline Dependent variables & Job satisfaction & 3.487 & 0.408 & & high \\
\hline
\end{tabular}

\subsection{Hypotheses Testing and Results}

For the purpose of testing the hypotheses of this research which is discussing the impact of the psychological empowerment on the job satisfaction, the authors applied the Multiple Linear Regression Analysis. 
Table 4. Results of the Multiple Linear regression analysis

\begin{tabular}{|c|c|c|c|c|c|c|c|c|c|}
\hline \multirow[t]{2}{*}{ Dependent variable } & \multicolumn{2}{|c|}{ Model summary } & \multicolumn{2}{|c|}{ ANOVA } & \multicolumn{2}{|l|}{ Coefficients } & \multirow[b]{2}{*}{$\begin{array}{l}\text { Standard } \\
\text { error }\end{array}$} & \multirow[b]{2}{*}{$\mathbf{T}$} & \multirow[b]{2}{*}{ Sig T } \\
\hline & $\mathbf{R}$ & R1 & $\mathbf{F}$ & Sig F & description & B & & & \\
\hline \multirow{4}{*}{ Job Satisfaction } & \multirow{4}{*}{0.707} & \multirow{4}{*}{0.500} & \multirow{4}{*}{41.964} & \multirow{4}{*}{0.000} & Sense of influence & 0.217 & 0.054 & 4.043 & 0.000 \\
\hline & & & & & Freedom of choice & 0.106 & 0.050 & 2.106 & 0.037 \\
\hline & & & & & Sense of capability & 0.189 & 0.049 & 3.890 & 0.000 \\
\hline & & & & & Sense of importance & 0.150 & 0.047 & 3.159 & 0.002 \\
\hline
\end{tabular}

Note. * the impact has a statistical significance if it is a $\leq 0.05$

The results contained in table 4 show that the correlation coefficient $(\mathrm{R}=0.707)$ refers to the relation between the independent variables and the dependent variable. The effect of the independent variables (psychological empowerment dimensions) on the dependent variable has a statistical significance. In fact the value of $\mathrm{F}$ is 41.964 and the sig. level is 0.000 which means less than 0.05 and it is clear that $\mathrm{R}^{2}=0.500$ which refers to $50.0 \%$ of disparity in job satisfaction and could be explained by the disparity in the psychological empowerment dimensions as a whole.

The transaction table shows that the value of $\mathrm{B}$ at (the sense of influence) dimension is 0.217 and $\mathrm{t}=4.043$ with $\mathrm{sig}=0.000$ and this means that the effect of this dimension is moral. With the dimension (freedom of choice), the value of $B$ is $0.106, t=2.106$ and sig $=0.037$ and this means that the effect of this dimension is moral. With the dimension (sense of capability), the value of $B$ is $0.189, t=3.890$ and sig $=0.000$ and this means that the effect of this dimension is moral. With the dimension (sense of importance), the value of $\mathrm{B}$ is $0.150, \mathrm{t}=3.159$ and sig $=0.002$ and this means that the effect of this dimension is moral.

\section{Discussion and Conclusions}

Despite the positive effect of the contribution, the Police College staff in developing each other and improving their performance, the general level of the sense of influence felt by the Police College employees was average. This is probably due to the lack of participation of the staff in matters related to the work environment as they think that their influence is limited to the ordinary matters which have no importance for the college. The college staff enjoy the freedom of dealing with the daily problems and enough independence to decide how to do their job and how to fulfill their duties and this means that the Police College grants its staff the freedom of choice in the matters relating to their work.

The College staffs have the ability to face the challenges they may face when performing their duties and have the confidence and determination to carry out the tasks assigned to them with efficiency. This shows their confidence in their capability and that they possess the capabilities allowing them to face challenges.

The police college staffs have the sense of responsibility towards their organization and consider their role as beneficial and important. This shows that they do care about their work and that they believe that the work they are doing is important. This indicates that the Police College is keen on making its staff feel the importance of their role.

The Police College provides its staff the opportunity to promote their knowledge and their skills and provides the sufficient support and the necessary means to help them perform their duties. Moreover, the college ensures the job security to its staff, which shows that it is keen to improve the quality of life of its employees and to meet their needs in order to create positive feelings in them and achieve the job satisfaction.

The results of the hypothesis test show the existence of a statistical effect of the psychological empowerment with its different dimensions (the sense of influence, the freedom of choice, the sense of capability and the sense of importance) in achieving the job satisfaction at the Police College and the moral effect was obvious in all dimensions, This confirms the importance of the psychological empowerment in achieving the job satisfaction. The results of this study were consistent with the results of the study conducted by (Abi Zayd, 2010) which concluded that there is no difference in the employees relation with the psychological empowerment due to personal variables. This study results also matched the results of a study by Namidi (2012) which concluded that there is a negative correlation between the psychological empowerment and the professional alienation and another study by Darraji (2018) which concluded the existence of an effect with a statistical significance of empowerment on the job satisfaction.

The results of the current study were also consistent with those of a study conducted by George (2013) and 
which concluded that the psychological empowerment increases the job satisfaction of the banking sector employees. However, it diverges from our study in that there is a correlation between the demographic variables of the employees (age and position) and the psychological empowerment. It is also consistent with a study by Joo et al (2013) which concluded that employees showed a higher level of job satisfaction when they are highly qualified (psychological empowerment) but it differs from it in terms of the importance of the effect of education level on the influence level of the employees. These results matched those of a study conducted by Hamady (2017) and which concluded that variables such as (the independence) and the (influence) have the highest impact on the job satisfaction and the performance. But it differs from it in terms of the inexistence of any effect of the qualification and the significance on the job satisfaction.

\section{Implications of the Study}

There are plenty of measures that could be taken by the Police College to improve the job satisfaction level of its staff. Among these measures, adopting methods and steps aiming to enhance their influence on the administrative and operational matters relating to the tasks assigned to them, and this would contribute in creating a feeling of importance and independence in the decision-making process and increases their personal efficiency in coping with the problems, hence reinforcing their psychological empowerment. The Police College could also try to enhance the contribution of its staff in the decisions and policies it makes through granting them sufficient power in performing their duties, encouraging them to take responsibility and providing the appropriate conditions for that, taking into account their opinions and their proposals which are commensurate with the organization's objectives and resources. Moreover, it should provide its staff with all necessary material and moral requirements to help them fulfill their duties which must be compatible with their capabilities and their skills in an appropriate work environment and through appropriate incentives allowing them to prove their capabilities and also through meeting their professional needs. Lastly, the Police College should create in its staff the feelings, thoughts and beliefs which contribute in the perception of the importance of their role through assigning them motivating activities and tasks which make them feel important and independent. It shall benefit from its staff experience and qualifications in conducting major tasks serving the organization and secure the professional stability for all its staff, praise their work and encourage their self-realization.

\section{Limitations and Future Research Directions}

The current study is aiming to discuss the impact of the psychological empowerment in achieving the job satisfaction at the Police College of Qatar, and suggest a study model. A sample was statistically analyzed and helped us better understand the impact of the psychological empowerment in achieving the job satisfaction. However, the study has some limitations. From the study results, it is worth noting that females are not represented in the survey because the staff is exclusively formed by males. This could impede our understanding of the impact of the psychological empowerment on the job satisfaction because the authors were not able to get the females' opinion as no females work at the Police College. Therefore there is a need to conduct more researches in colleges having a staff formed by both males and females to better understand the impact of the psychological empowerment in achieving the job satisfaction. On the other hand, the presented data were collected from one country which is Qatar, and therefore the results apply only to the Qatari context. This could raise the issue of generalization to different cultures and contexts. It takes more studies including police colleges from neighboring countries. The survey was the only tool to collect data in this research, therefore there is a need to include interviews in the future studies to gain a better understanding of the respondents opinions.

\section{References}

Aba zaid, R. (2010). The impact of psychological empowerment on the behavior of citizenship for employees of the Social Security Institution in Jordan. Najah University Journal of Humanities, 24(2), 494-519.

Abdissa, G., \& Fitwi, T. (2016). The Impact of Psychological Empowerment on Employees Job Satisfaction: With Reference to Commercial Bank of Ethiopia, Gedeo Zone. Pyrex Journal of Business and Finance Management Research, 2(7), 65-80.

Abu, T., Laith, S., Al-Kalabi, A. N., \& Abdel-Ameer, O. A. (2018). The Effect of Psychological Empowerment in Job Insecurity: An Applied Study in the Faculty of Management and Economics, University of Kufa. Journal of the Center for the Study of Kufa, 1(48), 185-210.

Abualoush, S., Habis, O., Abdallah, M., Tarhini, A., Masa'deh, R., \& Al-Badi, A. (2018). The role of employees' empowerment as an intermediary variable between knowledge Management and information systems on employees' performance. VINE Journal of Information and Knowledge Management Systems, 48(2), 217-237. https://doi.org/10.1108/VJIKMS-08-2017-0050 
Adel, A. R. H. (2010). Leadership and its relationship to job satisfaction. 1, Dar Al Yazuri Publishing and Distribution, Amman, Jordan.

AL Husseini, K. K. T. (2015). Psychological Empowerment: A Wealth to Promote Leadership Behavior, An Analytical Study of the Views of a Sample of Muthanna University Teachers. Al-Muthanna Journal of Administrative and Economic Sciences, 5(1), 171-188.

Al Sirafi, M. (2008). Administrative Behavior: Human Relations. Dar El Wafaa For Printing \& Publishing, Cairo, Egypt.

Al-Jedi, M. N. (2017). The impact of psychological empowerment on job satisfaction and job performance from the point of view of service personnel in the telecommunications sector in Jordan. Unpublished Master Thesis, Yarmouk University, Irbid, Jordan.

Al-Mu'aini, HashimRashedAjrashAfen (2018). Organizational Justice and its Impact on Organizational Commitment in Jordanian Private Universities: Job Satisfaction as an Intermediate Variant. Unpublished Master Thesis, Al-Bayt University, Mafraq, Jordan.

Al-Tai, R. A., \& Qudadah, A. (2008). General Quality management. Dar Alyazuri for printing and publishing, Amman, Jordan.

Belkhili, S., \& Aushet, H. (2012). The impact of job satisfaction on the performance of employees in university institutions, the case study of the University of Bouira. Unpublished MA, Institute of Economic and Commercial Sciences and Management Sciences, Algeria.

Ben Mowaffak, E. M., \& Ben, S. A. K. (2017). Job satisfaction and its impact on teacher performance: A comparative study between the teacher in the public school and the teacher at the private school in the state of Aljelfa. Master thesis unpublished, University of ZianAshour, Aljelfa, Algeria.

Bernie, L. (2014). Administrative Empowerment and its Impact on Enhancing Psychological Empowerment of Private Health Sector Workers in Biskra State. Economic and administrative research, (15).

Beryah, M. A. A., \& Mousawi, Y. (2016). Effect of Job Satisfaction on Human Resources Performance: A Case Study of the Public Hospital Establishment in Mughniyeh. Unpublished MA, University of Abu Bakr Belqayd, Tlemcen, Algeria.

Bysted, R. (2013). Innovation Employee Behavior: The Moderating Effects of Mental Involvement and Job Satisfaction on Contextual Variables. European Journal of Innovation Management, 16(3), 268-284. https://doi.org/10.1108/EJIM-09-2011-0069

Chegini, M. G., \& Abadi, M. V. (2013). The Relationship between Employees Empowerment with Job Satisfaction in Melli Bank of Guilen Province. Arabian Journal of Business and Management Review, 2(12), 71-79. https://doi.org/10.12816/0002363

Chong, W. Y., \& Lan, X. M. (2014). The Mediating Role of Psychological Empowerment between Transformational Leadership and Employee Work Attitudes. Procedia-Social and Behavioral Science, 172, 184-191. https://doi.org/10.1016/j.sbspro.2015.01.353

Cingoz, A., \& Kaplan, A. (2015). An Examination of the Mediating Role of Job Satisfaction on the Relationship between Psychological Empowerment and Innovation Behavior. International Review of Social Sciences, $3(2), 60-72$.

Daraji, F. O. H. (2018). The impact of transformational leadership on job satisfaction through empowerment in pharmaceutical institutions in Jordan. Unpublished Master Thesis, Amman Arab University, Amman, Jordan.

Demgrcg, A. E. (2010). Employee Empowerment and Its Effect on Organizational Performance. International Symposium on Sustainable Development, 2, 142-146.

Dewettinck, K., \& Ameijde, M. (2011). Linking Leadership Empowerment Behavior to Employee Attitudes and Behavioral Intentions. Personnel Review, 40(3). https://doi.org/10.1108/00483481111118621

Dickson, K. E. \& Lorenz, A. (2009). Psychological Empowerment and Job Satisfaction of Temporary and Part-Time Nonstandard Workers: A Preliminary Investigation. Institute of Behavioral and Applied Management, 199-191.

Gautam, D. K., \& Ghimire, S. B. (2017). Psychological Empowerment of Employees for Competitive Advantages: An Empirical Study of Nepalese Service Sector. International Journal of Law and 
Management, 59(4), 466-488. https://doi.org/10.1108/IJLMA-03-2016-0035

George, E. (2013). A Study on the Effect of Psychological Empowerment on Job Satisfaction and Job Related Stress among the Bank Employees. Doctor Thesis, Cochin University of Science and Technology, Kerala.

Ghoneim, A. H., \& Habib, A. M. (2018). Measuring the impact of strategic planning on job satisfaction using Balanced Scorecard at Bisha University Colleges. Journal of Economic and Administrative Sciences, 102(24), 196-212.

Greasley, K., Bryman, A., Pric, A., Naismith, N. \& Soetanto, R. (2008). Understanding Empowerment from one Employee Perspective. Team Performance Management, 14(1), 39-55. https://doi.org/10.1108/13527590810860195

Hajjaj, M. (2015). Work pressure and its impact on organizational loyalty: An applied study of managers working in the Ministry of Interior in the Gaza Strip. Unpublished MA, Islamic University, Gaza, Palestine.

Hamady, S. F. (2017). The Dimensions Psychological Empowerment (Competence, Job Meaning, Independency, and Impact) and Their Influence on the Employees' Effectiveness in the Iraqi Service Organizations. Humanities Journal of University of Zakho, 5(2), 429-445. https://doi.org/10.26436/2017.5.2.314

Hassan, F., Javed, M., \& Balouch, R. (2014). Determinants of Job Satisfaction and its Impact on Employee Performance and Turnover Intentions. International Journal of Learning and Development, 4(2), 120-140. https://doi.org/10.5296/ijld.v4i2.6094

Hussein, H. (2016). Effect of structural and psychological empowerment of employees on customer satisfaction, survey of private insurance companies in Lattakia. Unpublished Master Thesis, Syrian Virtual University, Syria.

Husseini, K. K. T. (2015). Psychological Empowerment: A Wealth to Promote Leadership Behavior, An Analytical Study of the Views of a Sample of Muthanna University Teachers. Al-Muthanna Journal of Administrative and Economic Sciences, (1).

Imam, A., \& Hassan, S. (2015). Psychological Empowerment and Engagement Resulting in Job Satisfaction of Employees Working in Service Industry of Pakistan: A Study of Nursing Staff. Science International (Lahore), 27(3), 2695-2702.

Indradevi, R. (2011). Employee Performance through Psychological Empowerment. Ganpat University-Faculty of Management Studies. Journal of Management and Research, 3, 19-33.

Jalab, I. D. (2011). Understanding organizational behavior in the age of change. 1, Dar Safa for Publishing and Distribution, Amman, Jordan.

Jaradat, N., Maani, A., \& Hashem, T. (2013). The Impact of Structural Empowerment on Achieving the Psychological Empowerment of Workers in Jordanian Public Organizations. Hebron University Journal of Research, 8(1), 63-89.

Joo, B., \& Lim, T. (2013). Transformational Leadership and Career Satisfaction: The Mediating Role of Psychological Empowerment. Journal of Leadership and Organizational Studies, 20(3), 316-326. https://doi.org/10.1177/1548051813484359

judah, R. J. (2010). Transformational leadership and its impact on job satisfaction from the perspective of subordinates in the Iraqi Ministry of Financial Resources. Unpublished Master Thesis, Yarmouk University, Irbid, Jordan.

Kermani, Z. Z. (2013). A Study if the Linking between Job Satisfaction and Customer Satisfaction: A Case Study of Iran Insurance, Karman, Iran. Journal of Marketing Development and Competitiveness, 7(4), 104-105.

Khalidi, K. A. F. (2018). Emotional Empowerment and its Effect on Creative Behavior: An Empirical Study in the Environment Directorate of Qadisiyah. Al-Muthanna Journal of Administrative Sciences, 8(1), 68-88.

Khalidi, K. A. F. (2018). Psychological Empowerment and its Effect on Creative Behavior: An Empirical Study in the Environment Directorate of Qadisiyah. Al-Muthanna Journal of Administrative and Economic Sciences, 8(1), 68-88.

Khanna, S., \& Gupta, V. (2016). The Impact of Psychological Empowerment on Job Satisfaction and Organizational Commitment. International Journal of Research in Organizational Behavior and Human Resource Management, 4(1), 24-36.

Lari, M. T., Shekari, G. A., \& Safizadeh, M. (2012). The Examination of Influence of Psychological 
Empowerment on Employee Innovation Behavior in the Social Security Organizational of Khorasan Razavi. Interdisciplinary Journal of Contemporary Research in Business, 4(8), p. 170-180.

Lour, A. (2014). Psychological Empowerment and its Impact on Organizational Citizenship of Civil Protection Personnel: An Empirical Study at the State Directorate of Skikda. Unpublished Master Thesis, Setif, Algeria.

Malhotra, N., \& Mukherjee, A. (2008). The Relative Influence of Organizational Commitment and Job Satisfaction on Service Quality of Customer A Contact Employees in Banking Call Centers. Journal of Services Marketing, 18(3), 162-174. https://doi.org/10.1108/08876040410536477

Mardani \& Mardani. (2014). The Impact of Psychological Empowerment on Job Burnout in Hospital Staff. International Journal of Hospital Research, 3(2), 69-78.

Masa'deh, R., Almajali, D. A., Alrowwad, A., \& Obeidat, B. (2019). The role of knowledge management infrastructure in enhancing job satisfaction: A developing country perspective. Interdisciplinary Journal of Infor-mation, Knowledge, and Management, 14, 1-25. https://doi.org/10.28945/4169

Meyerson, G., \& Dewettinck, B. (2012). Effect of Empowerment on Employees Performance. Advanced Research in Economic and Management Sciences (AREMS), 2, 40-46.

Mir, R. A., \& Rainayee, R. A. (2015). Employee Empowerment and its Outcomes: A Mediation Model. Pacific Business Review International, 8(6), 1-9.

Nzuv, S. M. \& Bakari, T. H. (2012). The Relationship between Empowerment and Performance in the City Council of Nairobi. Problems of Management in the 21 Century, 5, 83-98.

Obeidat, A. M., \& Otibi, G. A. (2015). The Impact of Knowledge Sharing Tools on Levels of Organizational Learning (Field Study on Jordanian Commercial Banks). Australian Journal of Basic and Applied Sciences, 9(5), 253-267.

Obeidat, A. M., Abualoush, S. H., Irtaimeh, H. J., Khaddam, A. A., \& Bataineh, K. A. (2018). The role of organisational culture in enhancing the human capital applied study on the social security corporation. Int. $J$. Learning and Intellectual Capital, 15(3), 258-276. https://doi.org/10.1504/IJLIC.2018.094718

Paktinat, E., \& Fathizadeh, A. (2008). Empowerment of Employees: Requirements and Solutions. Journal of Management Research, 11, 47-33.

Piriyathanalai, W., \& Muenjohn, N. (2012). Is There a Like? Employee Satisfaction and Service Quality. World Journal of Management, 4, 82-92.

Priyadharshany, J., \& Sujatha, S. (2015). Dose Structural Empowerment Impact on Job Satisfaction via Psychological Empowerment? A Mediation Analysis. Sona Global Management Review, 10(1), 23-42.

Qarkat, S. (2017). The impact of organizational trust in the achievement of psychological empowerment, field study in the Directorate of State Property of Biskra State. Unpublished Master Thesis, University of Mohamed KhaderBiskra, Algeria.

Saeidi, M., \& Asgari, M. H. (2016). The Relationship between Psychology Empowerment and Job Involvement of Employees in Islamic Azad University of Tonekabon Branch. Journal of Current Research in Science, $S(2), 451-458$.

Semih, T., \& Tugba, Z. (2016). Social Interactions in Job satisfaction. International Journal of Manpower, 37(3), 426-455. https://doi.org/10.1108/IJM-04-2014-0095

Shahin, H. S. S. (2015). Psychological Empowerment and Psychosocial occupational Combustion among Special Education Teachers. Journal of Educational Sciences, (2).

Spreitzer, G. M. (2008). Taking Stock: A Review of More than Twenty Years of Research on Empowerment at Work. In C. Cooper \& J. Barling (Eds.), Handbook of Organizational Behavior. Thousand Oaks, CA: Sage.

Sreenivas, J. N. (2014). Impact of Psychological Empowerment on Employee Performance: A Conceptual Review. Journal of Business and Management, 16(6), 1-5. https://doi.org/10.9790/487X-16620105

Sultan, M. (2014). Human behavior in organizations. New University House, Iskandarieh, Egypt.

Tamidi, Crane Mustafa Khaled (2010). The Effect of Psychological Empowerment in Functional Alienation: A Survey Study of the Opinions of the Heads of Scientific Departments at Dohuk University. Iraq.

Ugwu, F., Ike E., Maria, R., \& Sánchez, A. (2014). Linking Organizational Trust with Employee Engagement: 
The Role of Psychological Empowerment. Personnel Review, 43(3). https://doi.org/10.1108/PR-11-2012-0198

Wang, G. (2012). The Influence of Internal Service Quality on Employee Job Satisfaction at Taiwan Listed International Tourist Hotels: Using Organizational Culture as the Moderator. World Transactions on Engineering and Technology Education, 10(3), 174-183.

Wang, G., \& Lee, P. D. (2009). Psychological Empowerment and Job Satisfaction an Analysis of Interactive Effects. Group and Organizational Management, 271-296. https://doi.org/10.1177/1059601108330089

Wasihun, M. (2011). The Effect of Internal Service Climate and Psychological Empowerment on Employees, Job Satisfaction: The Case of EEPCO.

Zeglat, D., Al-Jaber, D., \& Al-Rawabdeh, W. (2014). Understanding the Impact of Employee Empowerment on Customer Oriented Behavior. Journal of Business Studies, 6(1), 103-2015.

\section{Copyrights}

Copyright for this article is retained by the author(s), with first publication rights granted to the journal.

This is an open-access article distributed under the terms and conditions of the Creative Commons Attribution license (http://creativecommons.org/licenses/by/4.0/). 